\title{
Recent patent applications in microarrays
}

Patent \#

WO 200518796

Subject

US 20050048580

US 20050048554

US 20050046758

A method for transcribing biomolecular patterns, involving two-dimensionally arranging biomolecules on a board, forming a thin-film layer made of an inorganic substance on the biomolecules, forming a supporting laye on the thin film layer, and peeling the thin film layer and the supporting layer off of the biomolecules together; useful for manufacturing biochips or devices using quantum dots or photonic crystals.

US 20050048648 A medium for reformulating biological membranes that enhances assay performance and is useful for fabricating and prolonging the shelf-life of biological membrane arrays.

US 20050048531 An array of nucleic acid probes, where each probe consists essentially of any of 127811 fully defined nucleotide sequences; useful for genetic analysis.

WO 200516869 New dendrimer compounds useful in biochips for detecting a target compound, and for methods of diagnosis and biochemical analysis.

US 20050042363 A microarray with a macroporous polymer substrate, manufactured by obtaining a macroporous polymer substrate and coating a surface with the substrate. The substrates have high immobilization capacity for large biomolecules and better accessibility of analytes to the immobilized biomolecules.

WO 200514852 A microarray of immobilized biomolecules comprising a surface carrying a pattern of separated regions, each containing several spots of biomolecules; for use in analysis and diagnosis.

KR 2004094982 A method for highly concentrating a target material in a sample using a scanning probe microscope to manufacture a highly integrated nano-bioarray.

\begin{tabular}{llcc} 
Assignee & Inventor(s) & \multicolumn{1}{c}{$\begin{array}{c}\text { Priority } \\
\text { application } \\
\text { date }\end{array}$} & $\begin{array}{c}\text { Publication } \\
\text { date }\end{array}$ \\
\hline $\begin{array}{l}\text { PamGene } \\
\text { (Hertogenbosch, } \\
\text { The Netherlands) }\end{array}$ & $\begin{array}{l}\text { Kievits T, } \\
\text { Ruijtenbeek R, } \\
\text { van Beuningen MG }\end{array}$ & $8 / 21 / 2003$ & $3 / 3 / 2005$ \\
$\begin{array}{l}\text { Harvard College } \\
\text { (Cambridge, MA, USA) }\end{array}$ & LaBaer J, Lau AY & $8 / 3 / 2004$ & $3 / 3 / 2005$ \\
& & & \\
& & & \\
Zhou J; Zhou X & Zhou J, Zhou X & $8 / 18 / 2004$ & $3 / 3 / 2005$
\end{tabular}

Omron KK (Tokyo);

Aoyama S;

Matsushita T;

Nisjikawa T;

Norioka S;

Tsuda Y; Wazawa T

Aoyama S,

$7 / 29 / 2003 \quad 3 / 3 / 2005$

Matsushita T,

Nisjikawa T,

Norioka S,

Tsuda Y,

Wazawa T

\section{Fang Y; Ferrie AM}

Fang Y, Ferrie AM

$8 / 29 / 2003$

$3 / 3 / 2005$

Affymetrix

Lockhart DJ,

$9 / 17 / 1998$

$3 / 3 / 2005$

(Santa Clara, CA, USA) Mack DH,

Pohang Iron and Choi KY, Choi YS,

Steel Co.; Pohang

Choi KY, Choi YS,
Hong BJ , Kwon SH

$8 / 19 / 2003$

$2 / 24 / 2005$

University of Science

and Technology Oh S], Park JW,

Foundation

(Pohang, Korea)

Chernov BK;

Youn TO

Gemmell MA;

Chernov BK,

Gemmell MA,

Golovaj B;

Golovaj B,

Kukhtin AV

Kukhtin AV,

Yershov GM

Yershov GM

SusTech GmbH \& Co. Groll J, Levi S,

$7 / 18 / 2003 \quad 2 / 17 / 2005$

(Darmstadt, Germany) Moeller M, Rong H

$8 / 18 / 2003$

$2 / 24 / 2005$

Sogang University

Choi JU, Chun BS,

$5 / 6 / 2003$

$11 / 12 / 2004$
Nam YS, Oh BG

Source: Derwent Information, Alexandria, VA. The status of each application is slightly different from country to country. For further details, contact Derwent Information,

1725 Duke Street, Suite 250, Alexandria, VA 22314. Tel: 1 (800) DERWENT (info.derwent.com). 